\title{
МОРАЛЬНІ ЗАСАДИ \\ ТРУДОВОГО ЗАКОНОДАВСТВА УКРАЇНИ
}

Козуб І. Г., Гетьманцева Н. Д.

\section{ВСТУП}

Норми трудового права врегульовують коло суспільних відносин, пов'язаних із реалізацією людиною права на працю, проте цими відносинами, звісно, предмет трудового права не обмежується. Така праця, що підпадає під регулювання норм трудового законодавства, $\epsilon$ несамостійною, а усуспільненою й організованою. Саме останнє вказує на взаємозв'язок людини праці із суспільством.

Трудове законодавство $\epsilon$ частиною національного законодавства, що свідчить про взаємозв'язок і вплив окремих галузей права на регулювання суспільних відносин. Мета такого регулювання є як загальною (для національного законодавства загалом), так і спеціальною (для окремих галузей права). Наявність загальної мети свідчить про єдність, загальність основних норм як права, так і моралі. Право і мораль постають основоположними елементами регулювання, впорядкування відносин у суспільстві й основоположними щодо здійснення правового впливу на поведінку суб'єктів. Правові норми не мають суперечити демократичним засадам суспільства, а засади суспільної моралі повинні братися до уваги органами державної влади щодо процедури розроблення нормативно-правових актів держави.

Оскільки трудова діяльність, яка здійснюється працівником у процесі виконання трудової функції, має характер усуспільненої праці 3 одночасним особистісним взаємозв'язком між людиною праці та роботодавцем, що виникає на підстав трудового договору, трудове законодавство базується як на загальних нормах моралі, так і на індивідуальних. Причому існування як і правового суспільства загалом, так і відокремленого трудового колективу чи взаємозв'язку людини праці - роботодавця без норм права і норм моралі складно уявити.

Питання сутності та значення моралі та права в регулюванні суспільних відносин ставали неодноразово предметом наукових досліджень вчених-правознавців, серед яких: В. Андрущенко, В. Бачинін, Т. Бутко, О. Зайчук, О. Козаченко, С. Мануйлов, Ю. Оборотов, Н. Оніщенко, О. Сидоренко, Г. Перетятко, М. Цвік, Д. Ядранський та ін. Незважаючи на вагомий внесок цих науковців у вивчення зазначеної тематики, на нинішньому етапі реформування трудового 718 
законодавства України повинно актуалізуватися дослідження моральних основ трудового законодавства як запоруки визнання людини найвищою соціальною цінністю у правовому, демократичному суспільстві.

\section{1. Моральність як одна із засад побудови правової демократичної держави}

Норми трудового законодавства пронизані моральними ідеями, вагома частка яких визнана на державному рівні та фактично становить моральні засади існування цивілізованого, правового, громадянського і демократичного суспільства. Саме моральні ідеї на відповідному історичному етапі розвитку суспільства були одними із тих чинників, що зумовили виникнення трудового права як окремої галузі, адже моральні норми впливають на характер і динаміку правових норм і зумовлюють виникнення, зміну та припинення дії останніх. Мораль трансформується залежно від економічного, інформаційного, культурного, духовного розвитку суспільства або індивідів. На відміну від моральних, правові норми здебільшого є обов'язковими до виконання, i їх невиконання тягне несприятливі правові наслідки. Правові норми обов'язкові для всіх незалежно від моральних переконань кожної окремої людини. У громадянському суспільстві $є$ моральним виконувати норми права, а їх невиконання є аморальним ${ }^{1}$. Наявність двох інститутів юридичної відповідальності - дисциплінарної та матеріальної - у трудовому праві свідчить про наявність як морального осуду з боку держави зі встановленими правовими наслідками до особи порушника, так і осуду з боку роботодавця, а також працівника (якщо йдеться про матеріальну відповідальність роботодавця) встановленого правопорядку. Водночас в окремих випадках у сфері праці деякі норми моралі набувають юридичного значення, тобто реалізація відповідних правових норм потребує звернення до норм моралі (йдеться про норми професійної етики, про аморальні вчинки, за які можуть застосовуватися заходи дисциплінарної відповідальності, тощо) ${ }^{2}$.

Невиконання моральних норм (ідей), які не відображені у правовій нормі, зазвичай не тягне негативних правових наслідків, а викликає осуд інших учасників суспільних відносин (звісно, з цього правила є винятки, коли чітко правило поведінки у нормі права не визначено,

\footnotetext{
1 Грабова О.В. Деякі аспекти співвідношення права та моралі на сучасному етапі. Альманах права. 2012. Вип. 3. С. 485.

2 Богуславская К.Ю. Взаимодействие норм права и норм морали в правовом регулировании трудовых отношений : автореф. дис. ... канд. юрид. наук : 12.00.05. Барнаул, 2006. С. 5.
} 
але сама норма закликає до виконання певних дій чи обов'язків відповідно до норм професійної етики чи моралі, тоді порушення вимог норми тягне негативні правові наслідки). Але саме правові норми втілюють ті основні загальновизнані моральні норми, які є основою існування демократичного, громадянського, правового суспільства. Тому ми поділяємо позицію тих науковців, котрі наголошують, що право це юридично оформлена мораль, тобто майже всі правові норми $є$ водночас нормами моралі ${ }^{3}$. Норми права $є$ однією із форм виразу норм моралі. Але це не означає, що будь-яка норма права відображає норму моралі. Так, наприклад, ст. 5 КЗПП України визначає, що законодавство про працю складається з Кодексу законів про працю України та інших актів законодавства України, прийнятих відповідно до нього 4 . Вказана норма не відображає норм суспільної моралі.

Звісно, не всі моральні ідеї визнаються державою і не мають прояву у правовій нормі. Більше того, сфера дії норм права і норм моралі часом не збігаються. Це логічно пояснюється наявністю широкого кола суспільних відносин, які не завжди підлягають правовому регулюванню. Наприклад, що стосується реалізації людиною іiї права на працю. Це право людина може реалізувати як шляхом вступу у правовідносини, так і не вступаючи у них. Зокрема, здійснення певного виду трудової діяльності на прохання одного із членів сім'ї чи друга, виконання трудової діяльності для задоволення власних духовних чи моральних потреб та ін. Вказані суспільні відносини і виконання трудової діяльності в таких випадках будуть регулюватися нормами моралі, як суспільної, так і окремих індивідів. Тому сфера дії норм моралі часом значно ширша, ніж норм права, і за об'ємом, а, враховуючи порівняно динамічнішу трансформацію норм суспільної моралі, останніх може бути більше. Йдеться саме про норми суспільної моралі, а не окремих індивідів. 3 огляду на вказане ми поділяємо позицію, відповідно до якої все, що регулюється правом, регулюється і мораллю, але не все, що регулюється мораллю, регламентується правом ${ }^{5}$.

Отже, визнані державою моральні ідеї у своїй сукупності стають моральними основами (засадами) законодавства і втілюються у норми права. Такі моральні ідеї, санкціоновані державою, фактично стають

\footnotetext{
3 Загальна теорія держави і права : підручник / М.В. Цвік, О.В. Петришин, Л.В. Авраменко та ін. ; за ред. М.В. Цвіка, О.В. Петришина. Харків : Право. С. 166.

4 Кодекс Законів про Працю України в редакції від 13 лютого 2020 p. URL: https://zakon.rada.gov.ua/laws/show/322-08.

5 Теория государства и права. Курс лекций / под ред. Матузова Н.И., Малько А.В. Москва : Юристъ, 2001. С. 335.
} 
суспільною мораллю, а дотримання норм є обов'язковим. Розуміння несправедливого ставлення до людини праці, котра зазнавала утисків з боку роботодавців, усвідомлення необхідності визнання рівноправності сторін трудових правовідносин на стадії укладення трудового договору з підляганням господарській владі роботодавця та багато ін. викликало необхідність із боку держави захистити працівника шляхом прийняття норм, які згодом у своїй сукупності утворили окрему галузь трудового права. Виникнення трудового права $є$ наслідком боротьби між різними соціальними групами (працівники і роботодавці) та їх ідеологіями і використовується людьми для досягнення власної мети, цілей. Саме тому у трудових відносинах вони потребують таких прав, як на мінімальну заробітну плату чи на свободу об'єднання для захисту своїх інтересів лише для того, щоб продовжити перебування у таких правовідносинах 6 . Основним призначенням цієї галузі є досягнення компромісу між інтересами роботодавця та працівника, балансу таких інтересів із забезпеченням охорони трудових прав працівників, встановлення високого рівня умов праці. Такий баланс інтересів можливий за дотримання не тільки норм права, що відображають суспільну мораль, а й моральних норм, не закріплених у правових нормах, що випливає не тільки із наявності взаємовідносин керівник - підлеглий, керівник - трудовий колектив, а й відносин усередині трудового колективу.

Яскравим прикладом втілення норм моралі є ст. 24 Конституції України, в якій наголошується, що громадяни мають рівні конституційні права і свободи та є рівними перед законом. Не може бути привілеїв чи обмежень за ознаками раси, кольору шкіри, політичних, релігійних та інших переконань, статі, етнічного та соціального походження, майнового стану, місця проживання, за мовними або іншими ознаками ${ }^{7}$. Фактично такі самі гарантії рівності та заборони дискримінації містяться й у низці міжнародних нормативно-правових актів, які в різні часи були ратифіковані Україною, ставши невід'ємною частиною національного законодавства. До таких актів, серед іншого, належать: Загальна декларація прав людини; Міжнародний пакт про громадянські і політичні права; Міжнародний пакт про економічні, соціальні і культурні права; Міжнародна конвенція про ліквідацію всіх форм расової дискримінації; Конвенція Організації Об’єднаних Націй

\footnotetext{
6 Brian Langille Labour Law's Theory of Justice. 2011. P. 103. URL: https://www.iea-nantes.fr/ rtefiles/File/brian-langille.pdf.

7 Конституція України. URL: https://zakon.rada.gov.ua/laws/show/254к/96-вр.
} 
про ліквідацію всіх форм дискримінації щодо жінок; Конвенція про права осіб з інвалідністю; Конвенція про захист прав людини і основоположних свобод, а також Протокол № 12 до неї; Свропейська соціальна хартія (переглянута); Рамкова конвенція про захист прав національних меншин та ін.

У трудовому законодавстві України норми щодо заборони дискримінації у сфері праці відображені у ст. 2-1 КЗПП України. Вказана норма слугує прикладом визнання на державному рівні моральних ідей про рівність, справедливість, гідність і честь, а також трансформації моральних ідей у моральні засади, норми права. Фактично в ній відображена суспільна мораль, яка за визначенням Закону України «Про захист суспільної моралі» становить систему етичних норм, правил поведінки, що склалися у суспільстві на основі традиційних духовних і культурних цінностей, уявлень про добро, честь, гідність, громадський обов'язок, совість, справедливість ${ }^{8}$.

Подібні норми щодо заборони дискримінації містяться і в інших нормативно правових актах національного законодавства у сфері трудового права, наприклад, у Законі України «Про державну службу»", в Законі України «Про засади запобігання та протидії дискримінації в Україні» ${ }^{10}$, сфера дії якого поширюється і на трудові відносини (ст. 4), та ін. Щодо останнього Закону хочемо відзначити, що він став однією із ланок наближення України до європейської практики у питаннях запобігання та протидії дискримінації.

Тому можна стверджувати, що трудове законодавство грунтується на засадах недискримінації, яка полягає у забезпеченні рівності прав i свобод осіб та/або груп осіб; забезпеченні рівності перед законом осіб та/або груп осіб; повазі до гідності кожної людини; забезпеченні рівних можливостей осіб та/або груп осіб. Такі засади вказують на єдність правового регулювання праці, що, до речі, й зумовлює диференціацію останнього. 3 метою забезпечення рівної можливості в реалізації трудових прав для окремих категорій працівників надаються додаткові гарантії їх трудових прав, що продиктовано, на наш погляд, вимогами норм суспільної моралі та дотриманням принципу соціальної справедливості. Щодо останнього принципу зазначимо, що його

\footnotetext{
8 Закон України «Про захист суспільної моралі» від 20 листопада 2003 р. № 1296-IV. URL: https://zakon.rada.gov.ua/laws/show/1296-15.

9 Закон України «Про державну службу» від 10 грудня 2015 р. № 889-VIII. URL: https://zakon.rada.gov.ua/laws/show/889-19.

10 Закон України «Про запобігання та протидію дискримінації» від 6 вересня 2012 р. № 5207-VI. URL: https://zakon.rada.gov.ua/laws/show/5207-17.
} 
не потрібно сприймати крізь призму тотожності прав і з цієї позиції оцінювати його дотримання. Він не слугує вимірником прав за їх кількістю. Навпаки, він ставить вимоги до справедливого розподілу прав між суб'єктами, що перебувають у неоднакових умовах, зумовлених об'єктивними (віком, статтю, станом здоров'я та ін., які не залежать від волі людини) та суб'єктивними факторами. У такому аспекті його можна визначити як ваги, на одному важелі яких стоять об'єктивні фактори, а на іншому - права. Так, за І.П. Жигалкіним: «Принцип справедливості проголошує: «Не всім одне й те саме, а кожному своє, оскільки для нерівних рівне б стало не рівним». Ця вимога змушує суспільство і державу прагнути досягнення справедливості. У цьому вбачається глибокий сенс правового регулювання, спрямованого на реалізацію торжества справедливості як правової цінності та морального імперативу. 3 поняття справедливості випливає, що рівні вимагають рівного ставлення з боку права, а різні - відмінного ставлення відповідно до різниці між ними» ${ }^{11}$.

Так, ст. 14 Закону України «Про зайнятість населення» ${ }^{12}$ визначено коло осіб, котрі потребують додаткових гарантій сприяння у працевлаштуванні. Звісно, диференціація правового регулювання праці здійснюється не тільки шляхом встановлення додаткових пільг і гарантій для окремих осіб, а й, наприклад, встановлення особливих вимог до тих осіб, які претендують на обіймання суспільно значущої посади, що також, у свою чергу, пов'язано із нормами моралі. Так, у ст. 148 Конституції України зазначено, що суддею Конституційного Суду України може бути громадянин України, який володіє державною мовою, на день призначення досяг сорока років, має вищу юридичну освіту і стаж професійної діяльності у сфері права щонайменше п'ятнадцять років, високі моральні якості та є правником із визнаним рівнем компетентності.

Окрім того, до окремих видів професійної трудової діяльності суспільство висуває підвищені моральні вимоги, передбачені положеннями окремих законів і підзаконних нормативно-правових актів (наприклад, щодо суддів, державних службовців та ін.). Відповідно до Загальних правил етичної поведінки державних службовців

11 Жигалкін І.П. Система принципів трудового права в умовах формування нової правової доктрини України : дис. ... докт. юрид. наук : 12.00.05. / Східноук. нац. ун-т ім. В. Даля. Сєвєродонецьк, 2016. С. 341-342.

12 Закон України «Про зайнятість населення» від 5 липня 2012 р. № 5067-VI. URL: https://zakon.rada.gov.ua/laws/show/5067-17. 
і посадових осіб місцевого самоврядування ${ }^{13}$ від 05 серпня 2016 р. державні службовці та посадові особи місцевого самоврядування під час виконання своїх посадових обов'язків зобов'язані неухильно дотримуватися загальновизнаних етичних норм поведінки, бути доброзичливими та ввічливими, дотримуватися високої культури спілкування (не допускати використання нецензурної лексики, підвищеної інтонації), 3 повагою ставитися до прав, свобод і законних інтересів людини і громадянина, об'єднань громадян, інших юридичних осіб, не проявляти свавілля або байдужість до їхніх правомірних дій і вимог.

Відштовхуючись від судження, що мораль - це також уявлення про справедливість, можна стверджувати: необхідність диференціації правового регулювання праці є нормою суспільної моралі, яка визнана на державному рівні та відображена у нормах трудового законодавства. Тому надання додаткових гарантій чи встановлення особливих вимог до окремих соціальних груп у жодному разі не потрібно розцінювати як дискримінацію. Із цього приводу в ст. 6 Закону України «Про засади запобігання та протидії дискримінації в Україні» зазначається, що не вважаються дискримінацією дії, які не обмежують права та свободи інших осіб і не створюють перешкод для їх реалізації, а також не надають необгрунтованих переваг особам та/або групам осіб за їх певними ознаками, стосовно яких застосовуються позитивні дії, а саме спеціальний захист із боку держави окремих категорій осіб, котрі потребують такого захисту; здійснення заходів, спрямованих на збереження ідентичності окремих груп осіб, якщо такі заходи є необхідними; надання пільг і компенсацій окремим категоріям осіб у випадках, передбачених законом; встановлення державних соціальних гарантій окремим категоріям громадян; особливі вимоги, передбачені законом, щодо реалізації окремих прав осіб.

Отже, реалізація принципу соціальної справедливості у трудовому законодавстві здійснюється шляхом диференціації правового регулювання праці, проте відображається не тільки в ньому. Цей принцип відображає моральні ідеї, визнані не тільки суспільством, а й державою. Становлення та розвиток принципу соціальної справедливості - складний історичний період, але на сучасному етапі його реалізація є саме тим, чого прагне будь-яке цивілізоване суспільство, i тим, чого прагне і трудове законодавство. Влучно з цього приводу

13 Загальні правила етичної поведінки державних службовців та посадових осіб місцевого самоврядування, затверджені Наказом Національного агентства України з питань державної служби 05 серпня 2016 р. № 158. URL: https://zakon.rada.gov.ua/laws/show/z1203-16. 
відзначає О.М. Ярошенко: «Перед трудовим законодавством за сучасних умов стоїть складне завдання: зробити правове регулювання праці соціально справедливим, адекватно відображаючи реалії суспільного життя, одночасно зберігши соціальне призначення трудового права, максимально захистивши інтереси працівника як найбільш уразливої сторони трудового договору. Ця мета може бути досягнута лише за умови високої внутрішньої організації системи трудового права, несуперечливості закладеного в іiї підгрунтя нормативно-правового матеріалу, ефективного поєднання норм цієї галузі права з приписами інших галузей... Виникла необхідність створення правової системи, орієнтованої не на жорстку державну регламентацію суспільних відносин, а на поєднання різних (переважно договірних) методів управління. Процес створення якісно нового законодавства перебуває в початковій стадії, наштовхується на численні рифи й підводні камені антидемократичного, а нерідко й авторитарного характеру, протистояння законодавчої й виконавчої гілок влади ${ }^{14}$ 》.

Повертаючись до рівності трудових прав, проголошеної у ст. 2 КЗпП України, відзначимо значний прогрес вітчизняного суспільства, що грунтується відповідно й на його нормах моралі. Так, у 2015 р. був прийнятий Закон України «Про внесення змін до Кодексу законів про працю України щодо гармонізації законодавства у сфері запобігання та протидії дискримінації з правом Європейського Союзу». Зазначеним законом був розширений перелік ознак, за якими у сфері праці забороняється дискримінація. Зокрема, до цього переліку включено такі ознаки, як сексуальна орієнтація та гендерна ідентичність. Таким чином, в Україні вперше на законодавчому рівні встановлено заборону дискримінації за вказаними ознаками у сфері праці. Вказане свідчить про значні кроки нашої держави на шляху до євроінтерації та вплив усталених норм європейської моралі на вітчизняне законодавство, зокрема трудове. Втім, на практиці українське суспільство у своїй більшості не готове сприймати нетрадиційну сексуальну поведінку як норму для певних соціальних груп, що відбивається на звуженні їх правових можливостей. Така ізоляція сексуальних меншин це не тільки трагедія людства, а й серйозний, самостійно нанесений економічний збиток. Адже існування такої нерівності погіршує якість людського потенціалу, уповільнює економічне зростання, ослаблює систему державного управління, знижує ефективність реалізації

14 Ярошенко О.М. Джерела Трудового права України : дис. ... докт. юрид. наук : 12.00.05. Нац. юрид. акад. ім. Ярослава Мудрого. Харків, 2007. С. 342. 
стратегій розвитку та боротьби з бідністю й, окрім того, впливає на рівень зайнятості та рівень безробіття ${ }^{15}$. Переважна більшість потерпілих через свою сексуальну орієнтацію у трудовій сфері не вживали ніяких дій, щоб відстояти свої права, вважаючи за краще звільнитися без галасу, за власним бажанням, щоб мати можливість працевлаштуватися в іншому місці ${ }^{16}$. Крім того, постійний тиск на гомосексуальних працівників дуже серйозно впливає на розвиток економіки. Можна виділити основні напрями негативного економічного впливу ЛГБТдискримінації у країнах, що розвиваються:

1. Нерівність на роботі - представники ЛГБТ-спільноти отримують меншу заробітну плату, ніж їхні колеги-гетеросексуали, що призводить до зменшення податкових надходжень і відтоку кваліфікованих кадрів за кордон.

2. Високий рівень бідності гомосексуалів призводить до збільшення витрат на соціальні програми по боротьбі 3 жебрацтвом і соціальною нерівністю.

3. Поганий стан здоров'я дискримінованих працівників - це поширення захворювань, зростання рівня депресії та суїцидальних нахилів серед працівників у рази, а також зниження загальної продуктивності праці. Звідси - значні витрати на вирішення проблем з охороною здоров'я, боротьбою з поширенням ВІЛ і т. д.

4. Значну частину ВВП може втратити країна через гомофобну політику ${ }^{17}$.

\section{2. Норми індивідуальної моралі та трудове законодавство України}

Продовжуючи наше дослідження, нагадаємо, що, окрім норм суспільної моралі, які визнаються моральними засадами трудового законодавства, останнє містить і норми, в яких ідеться про індивідуальну мораль окремих учасників трудових правовідносин. Зокрема, ст. 237-1 КЗпП України встановлює, що відшкодування власником

\footnotetext{
15 Горєлов Д.М. Стан та проблеми ЛГБТ-руху в Україні. Аналітична записка. URL: http://www.niss.gov.ua/articles/1206/.

16 Крок вперед, два назад: Становище ЛГБТ в Україні в 2010-2011рp. / О.О. Зінченков, М.Г. Касянчук, А.В. Кравчук, А.Ю. Маймулахін, О.І. Остапенко, С.П. Шеремет. Київ : Центр «Наш світ», 2011. 152 с.

17 Прожога І.В., Шелурина В.О. ЛГБТ громадяни на ринку праці. Дискримінація за ознакою сексуальної орієнтації та гендерної ідентичності на ринку в трудовій сфері. I Всеукраїнська науково-методична конференція «Освіта, наука та виробництво: розвиток і перспективи» 21 квітня 2016 р. м. Шостка. URL: https://essuir.sumdu.edu.ua/bitstream/123456789/47172/1/ Prozhoga_Gender.pdf.
} 
або уповноваженим ним органом моральної шкоди працівнику провадиться у разі, якщо порушення його законних прав призвели до моральних страждань, втрати нормальних життєвих зв'язків і вимагають від нього додаткових зусиль для організації свого життя ${ }^{18}$. У цьому разі моральна шкода має індивідуальний характер і $є$ оціночним поняттям.

Окрім того, про індивідуальну мораль йдеться також у ст. 25-1 КЗпП України, в якій закріплено, що власник вправі запроваджувати обмеження щодо спільної роботи на одному й тому самому підприємстві, в установі, організації осіб, котрі є близькими родичами чи свояками (батьками, подружжям, братами, сестрами, дітьми, а також батьками, братами, сестрами і дітьми подружжя), якщо у зв'язку з виконанням трудових обов'язків вони безпосередньо підпорядковані або підконтрольні один одному. На підприємствах, в установах, організаціях державної форми власності порядок застосування таких обмежень встановлюється законодавством ${ }^{19}$. Так, ст. 27 Закону України «Про протидію корупції» ${ }^{20}$ наголошує, що визначені категорії осіб не можуть мати у прямому підпорядкуванні близьких їм осіб або бути прямо підпорядкованими у зв'язку з виконанням повноважень близьким їм особам. Пряме підпорядкування - відносини прямої організаційної або правової залежності підлеглої особи від іiі керівника, в т. ч. через вирішення (участь у вирішенні) питань прийняття на роботу, звільнення з роботи, застосування заохочень, дисциплінарних стягнень, надання вказівок, доручень тощо, контролю за їх виконанням. Загалом, вказаний Закон містить багато норм моралі, визнаних державою щодо виконання трудової функції визначеного кола суб'єктів на яких поширює свою дію цей Закон. До речі, щодо останнього Закону України, то до його прийняття неодноразово закликала Парламентська Асамблея Рада Європи у рамках моніторингу виконання обов'язків і зобов'язань України. Негайне їх прийняття, як постійно підкреслювали міжнародні наглядачі, зумовлювалося необхідністю зміцнення антикорупційної законодавчої бази в Україні, приведення іiї у відповідність до європейських стандартів і створення дієвих сучасних механізмів протидії корупції ${ }^{21}$.

\footnotetext{
18 Кодекс Законів про Працю України в редакції від 13 лютого 2020 p. URL: https://zakon.rada.gov.ua/laws/show/322-08.

19 Там само.

20 Закон України «Про запобігання корупції» від 14 жовтня 2014 р. № 1700-VII. URL: https://zakon.rada.gov.ua/laws/show/1700-18.

21 Хавронюк M.I. Передмова до науково-практичного коментаря до Закону України «Про засади запобігання і протидії корупції». URL: https://pravo.org.ua/ua/news/2534-.
} 
Варто відзначити, що виконання працівником своїх обов'язків відповідно до ст. 139 КЗпП України, що наголошує на обов’язку працівників чесно і сумлінно, своєчасно і точно виконувати розпорядження власника або уповноваженого ним органу, додержувати трудової та технологічної дисципліни, вимог нормативних актів про охорону праці, дбайливо ставитися до майна власника, з яким укладено трудовий договір ${ }^{22}$, пов'язане з індивідуальними нормами моралі як працівника, так і роботодавця, що трактують честь і сумлінність. Окрім того, можливість притягнення до дисциплінарної та матеріальної відповідальності як працівника, так і роботодавця пов'язана із нормами моралі вказаних суб' єктів. Це пов'язано із правом зазначених осіб, а не з їхнім обов'язком щодо притягнення винної сторони трудового договору до відповідальності. Отже, норми права і норми моралі є принципово важливими нормами регламентації поведінки під час виконання своїх обов'язків працівниками та реалізації своїх прав роботодавцями щодо дотримання дисципліни праці на підприємстві, установі й організації. Норми моралі значною мірою дозволяють виявляти і враховувати індивідуальні особливості кожного працівника.

Отже, трудове законодавство пронизано численними нормами моралі. Нормативно закріпленими є норми суспільної моралі. Норми індивідуальної моралі, хоч і безпосередньо не відображені в нормі, але містять вказівки стосовно дотримання відповідних норм моралі. Причому правовим захистом користуються і норми індивідуальної моралі (моральна шкода). Варто додати, що з приводу останнього національне трудове законодавство перебуває у процесі трансформації, і це також пов' язано із впливом європейського законодавства. Так, відповідно до законопроекту «Про працю» забороняється будь-яке упереджене ставлення у сфері праці та мобінг працівників, зокрема психологічний та/або економічний тиск, цькування, висміювання, наклеп, ізоляція, приниження гідності, створення ворожої, образливої атмосфери, нестерпних умов праці, умисний, систематичний і необгрунтований нерівномірний розподіл навантаження і завдань між працівниками, котрі виконують аналогічну роботу, нерівна оплата праці за аналогічну працю або працю рівної цінності ${ }^{23}$. Відповідно ж до законопроекту «Про внесення змін до деяких законодавчих актів України

\footnotetext{
22 Кодекс Законів про Працю України в редакції від 13 лютого 2020 p. URL: https://zakon.rada.gov.ua/laws/show/322-08.

23 Законопроект «Про працю» від 28 грудня 2019 р. № 2708. URL: http://search.ligazakon. ua/1_doc2.nsf/link1/JI01112A.html.
} 
щодо протидії мобінгу» від 01 березня 2019 р. № 10118 мобінг (цькування), тобто діяння учасників трудових відносин, які полягають у психологічному, фізичному, економічному насильстві, у т. ч. із застосуванням засобів електронних комунікацій, що вчиняються стосовно працівника підприємства, установи, організації незалежно від форми власності, виду діяльності та галузевої належності, а також осіб, які працюють за трудовим договором із фізичними особами або такою особою щодо інших учасників трудових відносин із метою приниження їх людської гідності за певними ознаками, створення стосовно них напруженої, ворожої, образливої атмосфери та примушування учасника трудових відносин до зміни місця роботи ${ }^{24}$.

Особи, котрі вважають, що вони зазнали дискримінації, упередженого ставлення у сфері праці, мобінгу, мають право звернутися до суду із заявою про відновлення порушених прав, відшкодування матеріальної та моральної шкоди. Такі особи зобов'язані навести факти наявності дискримінації, упередженого ставлення у сфері праці, мобінгу. Обов'язок доказування відсутності цих фактів покладається на роботодавця. Наприклад, відповідно до ст. 5 Закону України «Про засади запобігання та протидії дискримінації в Україні» однією із форм дискримінації є утиск, який відповідно до ст. 1 цього Закону визначається як небажана для особи та/або групи осіб поведінка, метою або наслідком якої є приниження їх людської гідності за певними ознаками або створення стосовно такої особи чи групи осіб напруженої, ворожої, образливої або зневажливої атмосфери. Утиск може набувати форм:

- словесних образ, коментарів або натяків, спрямованих на приниження гідності людини через, наприклад, їі колір шкіри, етнічну належність, стать, інвалідність, сексуальну орієнтацію тощо;

- образливих сексистських, гомофобних, антисемітських тощо жартів, анекдотів, кпинів;

- публічного (зокрема в межах спільного робочого простору) поширення сексистських, ксенофобних, гомофобних та інших печатних або графічних матеріалів (постерів, листівок, брошур тощо);

- образливих жестів сексистського або ксенофобного характеру;

- ігнорування, ізоляції або сегрегації через стать, етнічну належність, сексуальну орієнтацію тощо;

\footnotetext{
24 Законопроект «Про внесення змін до деяких законодавчих актів України щодо протидії мобінгу» від 01 березня 2019 р., № 10118. URL: http://search.ligazakon.ua/1_doc2.nsf/link1/ JH7T200A.html.
} 
- актів фізичної агресії та насильства. Безперечно, цей перелік не $\epsilon$ вичерпним, оскільки перелічити усі можливі форми утиску неможливо через їхню чисельність ${ }^{25}$.

Таким чином, особа, яка зазнає утиску у будь-якій формі його прояву, зазнає і дискримінації. У доповіді ООН «Дискримінація в Україні: очевидна і прихована» стверджується, що дискримінація в Україні є справжньою проблемою, яка може торкнутися кожного, незалежно від статі, віку чи стану здоров'я. «Расова належність, колір шкіри, національна або етнічна належність, стать, гендер і гендерна ідентичність, вік, стан здоров'я, громадянство (або його відсутність), сімейний і шлюбний стан, соціальний стан, рід занять, майновий стан, місце проживання, ставлення до релігії, конфесійна належність...» ${ }^{26}$ - ось далеко не повний проявів дискримінації, про які зазначається в доповіді ${ }^{27}$.

Звісно, вищезазначені правові норми, які закріплюють норми моралі, не вичерпують приклади визнання державою моральних норм, що містяться у трудовому законодавстві України. Вказане свідчить про потребу подальших наукових досліджень у цій сфері. Більше того, моральні норми, звичаї та традиції, що складися у певному суспільстві, багато в чому визначають взаємини між людьми у процесі праці. Такі взаємини впливають як на якість трудового життя працівника, так і на результати його праці, в яких неабияк зацікавлений роботодавець. Тому відносини керівник - підлеглий, керівник - трудовий колектив, а також ті, що існують усередині трудового колективу, базуються не тільки на нормах права, а й на нормах моралі, і також мають стати предметом подальшого наукового аналізу.

\section{ВИСНОВКИ}

Визнані державою моральні ідеї у своїй сукупності стають моральними основами (засадами) законодавства і втілюються у нормах права. Такі моральні ідеї, санкціоновані державою, фактично стають суспільною мораллю, а дотримання їх норм є обов'язковим.

\footnotetext{
25 Запобігання та протидія дискримінації в Україні: Посібник для працівників органів державної влади та місцевого самоврядування. Київ : Міжнародна організація з міграції, Представництво в Україні, 2014. С. 21.

26 Дискримінація в Україні: очевидна і прихована. OOH. URL: http://www.un.org.ua/ua/ informatsiinyi-tsentr/news/3041-2013-02-05-13-58-30-diskriminaciya-v-ukrayini-oche.

27 Наближення України до європейської практики у питаннях запобігання та протидії дискримінації. URL: https://eu-ua.org/analityka/nablyzhennya-ukrayiny-do-yevropeyskoyipraktyky-u-pytannyah-zapobigannya-ta-protydiyi.
} 
Трудове законодавство грунтується на засадах недискримінації, яка полягає у забезпеченні рівності прав і свобод осіб та/або груп осіб; забезпеченні рівності перед законом осіб та/або груп осіб; повазі до гідності кожної людини; забезпеченні рівних можливостей осіб та/або груп осіб. Такі засади вказують на єдність правового регулювання праці, яка, до речі, й зумовлює диференціацію останнього. 3 метою забезпечення рівної можливості в реалізації трудових прав для окремих категорій працівників надаються додаткові гарантії їх трудових прав, що продиктовано вимогами норм суспільної моралі та дотриманням принципу соціальної справедливості, який не потрібно сприймати крізь призму тотожності прав і з цієї позиції оцінювати його дотримання. Він не слугує вимірником прав за їх кількістю. Навпаки, він ставить вимоги до справедливого розподілу прав між суб'єктами, котрі перебувають у неоднакових умовах, зумовлених об'єктивними та суб'єктивними факторами. У такому аспекті його можна визначити як ваги, на одному важелі яких стоять об’єктивні фактори, а на іншому - права.

Диференціація правового регулювання праці здійснюється не тільки шляхом встановлення додаткових пільг і гарантій для окремих осіб, а й, наприклад, у встановленні особливих вимог до тих осіб, котрі претендують на обіймання суспільно значущої посади, що також пов'язано із нормами моралі. Необхідність диференціації правового регулювання праці є нормою суспільної моралі, визнаною на державному рівні та відображеною у нормах трудового законодавства.

Реалізація принципу соціальної справедливості у трудовому законодавстві здійснюється шляхом диференціації правового регулювання праці, проте відображається не тільки в ньому. Цей принцип відображає моральні ідеї, визнані не тільки суспільством, а й державою. Становлення та розвиток принципу соціальної справедливості пройшло складний історичний період, але на сучасному етапі його реалізація $є$ саме тим, чого прагне будь-яке цивілізоване суспільство.

\section{АНОТАЦІЯ}

Право і мораль є способами регулювання та впорядкування відносин у суспільстві. Правовий виплив на поведінку суб'єктів правовідносин здійснюється шляхом використання як норм права, так і норм моралі. Правові норми втілюють ті основні загальновизнані моральні норми, які є основою існування демократичного, громадянського, правового суспільства. Норми права є однією із форм виразу норм моралі. Але це не означає, що будь-яка норма права відображає норму моралі. 
Не всі моральні ідеї визнаються державою і таким чином не мають прояву у правовій нормі. Сфери дії норм права і норм моралі часом не збігаються. Це пояснюється наявністю широкого кола суспільних відносин, які не завжди підлягають правовому регулюванню.

Трудове законодавство грунтується на засадах заборони дискримінації у сфері праці. Таке нормативне закріплення слугує прикладом визнання на державному рівні суспільних моральних ідей про рівність, справедливість, гідність і честь, а також трансформації моральних ідей у моральні засади, норми права. Зазначені засади трудового законодавства вказують на єдність правового регулювання праці, яка, до речі, й зумовлює диференціацію останнього. 3 метою забезпечення рівної можливості в реалізації трудових прав для окремих категорій працівників надаються додаткові гарантії їх трудових прав, що продиктовано вимогами норм суспільної моралі та дотриманням принципу соціальної справедливості.

Окрім норм суспільної моралі, які визнаються моральними засадами трудового законодавства, останнє містить і норми, в яких ідеться про індивідуальну мораль окремих учасників трудових правовідносин.

\section{ЛІТЕРАТУРА}

1. Грабова О.В. Деякі аспекти співвідношення права та моралі на сучасному етапі. Альманах права. 2012. Вип. 3. С. 484-487. URL: http://dspace.nbuv.gov.ua/handle/123456789/63976.

2. Богуславская К.Ю. Взаимодействие норм права и норм морали в правовом регулировании трудовых отношений : автореф. дис. ... канд. юрид. наук : 12.00.05. Барнаул, 2006. 22 с. URL: http://law.edu.ru/book/ book.asp ?bookID $=1280127$.

3. Загальна теорія держави i права: підручник / М.В. Цвік, О.В. Петришин, Л.В. Авраменко та ін. ; за ред. М.В. Цвіка, О.В. Петришина. Харків : Право. 584 с.

4. Кодекс Законів про Працю України в редакції від 13 лютого 2020 р. URL: https://zakon.rada.gov.ua/laws/show/322-08.

5. Теория государства и права. Курс лекций / под ред. Матузова Н.И., Малько А.В. Москва : Юристь, 2001. 776 с.

6. Brian Langille Labour Law's Theory of Justice. 2011. URL: https://www.iea-nantes.fr/rtefiles/File/brian-langille.pdf DOI: 10.1093/ acprof:oso/ 9780199693610.001.0001.

7. Конституція України. URL: https://zakon.rada.gov.ua/laws/show/ 254к/96-вр.

8. Закон України «Про захист суспільної моралі» від 20 листопада 2003 p. № 1296-IV. URL: https://zakon.rada.gov.ua/laws/show/1296-15. 
9. Закон України «Про державну службу» від 10 грудня 2015 р. № 889-VIII. URL: https://zakon.rada.gov.ua/laws/show/889-19.

10. Закон України «Про запобігання та протидію дискримінації» від 6 вересня 2012 р. № 5207-VI. URL: https://zakon.rada.gov.ua/laws/ show/5207-17

11. Жигалкін І.П. Система принципів трудового права в умовах формування нової правової доктрини України : дис. ... докт. юрид. наук : 12.00.05 / Східноук. нац. ун-т ім. В. Даля. Сєвєродонецьк, 2016. 449 с.

12. Закон України «Про зайнятість населення» від 5 липня 2012 р. № 5067-VI. URL: https://zakon.rada.gov.ua/laws/show/5067-17.

13. Загальні правила етичної поведінки державних службовців та посадових осіб місцевого самоврядування, затверджені Наказом Національного агентства України з питань державної служби 05 серпня 2016 p. № 158. URL: https://zakon.rada.gov.ua/laws/show/z1203-16.

14. Ярошенко О.М. Джерела Трудового права України : дис. ... докт. юрид. наук : 12.00.05. / Нац. юрид. акад. ім. Ярослава Мудрого. Харків, 2007. $476 \mathrm{c}$.

15. Горєлов Д.М. Стан та проблеми ЛГБТ-руху в Україні. Аналітична записка. URL: http://www.niss.gov.ua/articles/1206/.

16. Крок вперед, два назад: Становище ЛГБТ в Україні в 20102011 рр. / О.О. Зінченков, М.Г. Касянчук, А.В. Кравчук, А.Ю. Маймулахін, О.І. Остапенко, С.П. Шеремет. Київ : Центр «Наш світ», 2011. 152 с.

17. Прожога I.В., Шелурина В.О. ЛГБТ громадяни на ринку праці. Дискримінація за ознакою сексуальної орієнтації та гендерної ідентичності на ринку в трудовій сфері. I Всеукраӥнська науковометодична конференція «Освіта, наука та виробництво: розвиток і перспективи» 21 квітня 2016 р., м. Шостка. URL: https://essuir.sumdu. edu.ua/bitstream/123456789/47172/1/ Prozhoga_Gender.pdf.

18. Закон України «Про запобігання корупції» від 14 жовтня 2014 р. № 1700-VII. URL: https://zakon.rada.gov.ua/laws/show/1700-18.

19. Хавронюк M.I. Передмова до науково-практичного коментаря до Закону України «Про засади запобігання і протидії корупції». URL: https://pravo.org.ua/ua/news/2534-.

20. Законопроект «Про працю» від 28 грудня 2019 р. № 2708. URL: http://search.ligazakon.ua/1_doc2.nsf/link1/JI01112A.html.

21. Законопроект «Про внесення змін до деяких законодавчих актів України щодо протидії мобінгу» від 01 березня 2019 р., № 10118. URL: http://search.ligazakon.ua/__doc2.nsf/link1/JH7T200A.html.

22. Запобігання та протидія дискримінації в Україні : Посібник для працівників органів державної влади та місцевого самоврядування. Київ : Міжнародна організація з міграції, Представництво в Україні, 2014. 
74 c. URL: http://iom.org.ua/sites/default/files/iom_booklette-06_1kolonka_ screen.pdf.

23. Дискримінація в Україні: очевидна і прихована. OOH. URL: http://www.un.org.ua/ua/informatsiinyi-tsentr/news/3041-2013-0205-13-58-30-diskriminaciya-v-ukrayini-oche.

24. Наближення України до європейської практики у питаннях запобігання та протидії дискримінації URL: https:/eu-ua.org/analityka/ nablyzhennya-ukrayiny-do-yevropeyskoyi-praktyky-u-pytannyahzapobigannya-ta-protydiyi.

\section{Information about authors:}

Kozub I. H.,

Ph.D. (Candidate) in Law, Associate Professor, Associate Professor of the Department of Private Law Yurii Fedkovych Chernivtsi National University 19, Universytetska street, Chernivtsi, Ukraine Getmantseva N. D., Ph.D. in Law, Associate Professor, Head of the Department of Private Law Yurii Fedkovych Chernivtsi National University 19, Universytetska street, Chernivtsi, Ukraine

DOI https://doi.org/10.30525/978-9934-588-43-3/2.8 